DOI: $10.22616 /$ j.balticsurveying.2018.016

\title{
PROPOSALS FOR CLASSIFICATION AND EVALUATION OF LAND DEGRADATION IN LATVIA
}

\author{
Anda Jankava, Velta Parsova, Eva Laizane, Maija Berzina, Aina Palabinska \\ Department of Land Management and Geodesy \\ Latvia University of Life Sciences and Technologies
}

\begin{abstract}
Land degradation is one of the most pressing problems ensuring sustainable use of land. In order to provide a clear understanding of land degradation and its risks, as well as to implement unified measures for prevention of land degradation in Latvia, the Land Management Law came into force in 2015. It individually defines the concepts of land and soil degradation, thus separating them from each other, as well as clarifying the term "degraded territory". However, despite these solutions in the regulatory framework of the land degradation, till now criteria for identifying land degradation have not been developed and approved, therefore their determination is very subjective and not comparable between municipalities and at the state level. The aim of the article is to develop and approbate degradation criteria for assessing land degradation in particular territory. In the article, based on the author's previous studies on the classification of land degradation, characterised one type of land degradation - the abandoned agricultural and forestry activity territory, as well as proposed subdivision of criteria classification into three levels - low, medium and high. As result of the study, it was concluded that the classification of degraded territories into three degradation levels is justified for the purpose of more objective identification and evaluation of land degradation.
\end{abstract}

Key words: degradation level, degraded territory, land degradation, land management, land use

\section{Introduction}

Attention to land use and land management issues is being paid all over the world, because land is limited resource and its rational use is the foundation of the prosperity and development of every country. Land degradation is pending matter affecting sphere of land management. It is a process caused by human activity or climatic conditions, which reduces the useful properties of the land and, hence, the area of land used. Land degradation has become one of the biggest challenges not only in Europe but worldwide. This is also indicated by the soil scientist P. Buloks, who bases his view on statistics - about six million hectares of land are lost every year due to soil erosion, desertification affects about one sixth of the world's population and one fourth of the world's land, while the salinity of the soil affects about 20 millions of hectares of irrigated land (Bullock, 2005).

Although land degradation problems have been recognized for decades, government of Latvia started to focus seriously on this issue only in 2006, which by UN was announced as international year of deserts and land degradation. In the same year, the Ministry of the Environment of Latvia started to implement land degradation measures appointed in the Development Program of UN and Global environment facility project "UN Convention on the development of sustainable capacity and responsibility for implementation of the elimination of land degradation in Latvia", conducting investigation on changes of land quality and land degradation in several municipalities (Puce, 2006). Since then, several research and practical projects have been developed (Degradeto teritoriju izpēte..., 2004; Degradeto teritoriju un..., 2012; Jackson et al, 2012), which confirmed the fact that the problem of land degradation, defined both at international and European level, is very topical in Latvia as well. Latvia is not affected by the problem of desertification, however, land degradation is observed in various ways.

Both foreign and Latvian scientists have paid considerable attention to soil and land degradation in their studies, however, as pointed out by some scientific sources (Klavins et al., 2008), it is reasonable to pay attention to the fact that in most of the publications mainly is described soil degradation, its impact and prevention measures. However, soil degradation is just one of the causes of land degradation (Kasparinskis, 2014). When reading special literature, can be concluded that there is not one single definition of what is land degradation. In different sources it is defined in different ways, 
and conditions that affect land degradation are defined differently. However, many authors describe land degradation as a reduction of the natural and beneficial characteristics of the land, or even loss resulting from natural processes and human activities (Sklenicka, 2016).

In order to provide a clear understanding on land degradation and its risks, as well as to implement unified measures for its prevention, in Latvia relatively recently (since 2015) the Land Management Law was promulgated. It defines the soil degradation and land degradation as separate terms, thus separating them from each other. There is provided an explanation of degraded territory - it is a territory with destroyed or damaged upper layer of ground or an abandoned territory of construction, extraction of mineral resources, economic or military activities (Zemes parvaldibas likums, 2014). However, despite these solutions in the regulatory framework of the land degradation process, till now criteria for land degradation identifying have not been developed and approved, therefore their determination is very subjective and not comparable between municipalities and at the national level. Similarly, does not exist adequate classification of degraded territories, there is no regulation on the procedure for identifying and assessing the current level of land degradation and its feasibility, as well as for measures to prevent land degradation.

Solving this issue and making interviews and inquiries with specialists, considerable number of experts pointed out that degraded territories should be classified according to their characteristics or criteria, and to pay more attention to the degree of degradation (low, medium, high) that could facilitate their assessment and prevention. Based on the definition of degraded territory given in the Land Management Law and previous researches of the authors, there are developed proposals of classification of degraded territories and set of land degradation criteria (Parsova, Jankava, et. al., 2017) (Table 1).

Table 1

Proposals for classification of degraded territories

\begin{tabular}{|c|c|c|}
\hline No & The type of degraded territory & Criteria for the determination of degraded territory \\
\hline \multirow{6}{*}{1.} & \multirow{6}{*}{ Degraded built-up territory } & Depreciation of the buildings \\
\hline & & Built-up territory overgrown with bushes \\
\hline & & Pollution \\
\hline & & Dump-site \\
\hline & & The abandoned production territory or facility \\
\hline & & Abandoned military territory or object \\
\hline 2. & $\begin{array}{l}\text { Non-recultivated territory of mining of } \\
\text { mineral deposits }\end{array}$ & $\begin{array}{l}\text { Abandoned territory of extraction of peat and construction } \\
\text { materials }\end{array}$ \\
\hline \multirow{7}{*}{3.} & \multirow{7}{*}{$\begin{array}{l}\text { Unmanaged agriculture and forestry } \\
\text { activity territory }\end{array}$} & Agricultural land overgrown with bushes \\
\hline & & Dump-site \\
\hline & & Abandoned production territory or object \\
\hline & & Abandoned military territory or object \\
\hline & & Invasive plants \\
\hline & & Bogged-up land \\
\hline & & Pollution \\
\hline
\end{tabular}

On the basis of classification given in Table 1, this paper proposes to analyse one of the types unmanaged agriculture and forestry activities territory, as well as breakdown of each criterion for the determination of degraded territory into degradation levels.

\section{Methodology of research and materials}

The aim of the article is to develop proposals for degradation levels of each degradation criterion, to give characteristics (parameters) of each degradation level, as well as approbate these parameters. To achieve the goal, the following tasks have been set:

- to identify and describe degradation levels of each degradation criterion;

- to approbate land degradation parameters in a particular territory, surveying it, identifying and evaluating degraded areas in accordance with degradation levels. 
Based on scientific publications, inquiries of experts, as well as authors' considerations (Sklenicka, 2016; Kust et al., 2016), has been made the subdivision of degradation criteria of unmanaged agriculture and forestry activities territory into three levels - low, medium and high. Description of degradation levels has been made taking into account land degradation volumes, surveying feasibility and priorities of its elimination (Table 2).

Table 2

Description of levels of degradation criteria of unmanaged agriculture and forestry activities territory

\begin{tabular}{|c|c|c|c|}
\hline \multirow{2}{*}{ Degradation criteria } & \multicolumn{3}{|c|}{ Degradation level } \\
\hline & low & medium & high \\
\hline $\begin{array}{l}\text { Agricultural land } \\
\text { overgrown with shrubs }\end{array}$ & $\begin{array}{l}10-39 \% \text { of agricultural } \\
\text { land }\end{array}$ & $\begin{array}{l}40-69 \% \text { of agricultural } \\
\text { land }\end{array}$ & $\begin{array}{l}70-100 \% \text { of agricultural } \\
\text { land }\end{array}$ \\
\hline Uncultivated dump-site & area up to $50 \mathrm{~m}^{2}$ & area $50 \mathrm{~m}^{2}$ to $200 \mathrm{~m}^{2}$ & area above to $200 \mathrm{~m}^{2}$ \\
\hline $\begin{array}{l}\text { Abandoned territory or } \\
\text { object of production }\end{array}$ & $\begin{array}{l}\text { economic activities does } \\
\text { not take place for } 3 \text { years }\end{array}$ & $\begin{array}{l}\text { economic activities does } \\
\text { not take place for } 3 \text { to } 7 \\
\text { years }\end{array}$ & $\begin{array}{l}\text { economic activities does } \\
\text { not take place for more } \\
\text { than } 7 \text { years }\end{array}$ \\
\hline $\begin{array}{l}\text { Abandoned territory or } \\
\text { object of military } \\
\text { purpose }\end{array}$ & $\mathrm{X}$ & $X$ & $\begin{array}{l}\text { the objects has not been } \\
\text { demolished, the territory } \\
\text { has not been reclaimed }\end{array}$ \\
\hline $\begin{array}{l}\text { The invasive plants } \\
\text { (hogweeds) }\end{array}$ & $\begin{array}{l}\text { hogweeds occupies up to } \\
30 \% \text { of the area }\end{array}$ & $\begin{array}{l}\text { hogweeds occupies } \\
31-50 \% \text { of the area }\end{array}$ & $\begin{array}{l}\text { hogweeds occupies over } \\
51 \% \text { of the area }\end{array}$ \\
\hline Bogged-up land & $\begin{array}{l}\text { insignificant bogging-up, } \\
\text { there are drainage systems } \\
\text { requiring maintenance }\end{array}$ & $\begin{array}{l}\text { significant bogging-up, } \\
\text { there are drainage systems } \\
\text { requiring maintenance or } \\
\text { reconstruction }\end{array}$ & $\begin{array}{l}\text { bogging-up is in } \\
\text { territories without } \\
\text { drainage systems, } \\
\text { construction of them is } \\
\text { necessary }\end{array}$ \\
\hline Pollution & $\mathrm{X}$ & $X$ & $\begin{array}{l}\text { if the polluted territory is } \\
\text { registered in the Register } \\
\text { of Polluted and Potentialy } \\
\text { Polluted places }\end{array}$ \\
\hline
\end{tabular}

Further in the article is given a description of levels of degradation criteria and characteristics (parameters) of their assessment.

Agricultural land overgrown with shrubs. Abandoned or unused agricultural land is considered agricultural land which is not used for agricultural production, as well as land overgrown with shrubs, except forest land. In future for unused agricultural land can be two options - gradual natural or artificial afforestation, or removal of shrubs. If agricultural land is slightly overgrown with shrubberies it would not be considered as degraded territory, but if the territory is covered with shrubs in the amount of $10 \%$ to $39 \%$ of total area, it could be considered as low degradation level, medium degradation level could be in the amount of $40 \%$ to $69 \%$ and high - $70 \%$ to $100 \%$.

Uncultivated dump-site. An uncultivated dump-site is a place where no measures have been taken to prevent the negative effects of waste on human health and the environment (Atkritumu poligonu ierikošanas..., 2011). It is foreseen to arrange dump-sites only in building areas where the purpose of land use is "building area of waste management companies", therefore, any waste disposal site in agricultural or forest land is considered illegal (Nekustama ipasuma lietošanas..., 2006). Even small uncultivated dump-site in agricultural or forest land is considered to be an expression of land degradation. Low degradation level could occur if dump-site occupies an area of up to $50 \mathrm{~m}^{2}$, medium degradation level - if dump-site occupies an area from $50 \mathrm{~m}^{2}$ to $200 \mathrm{~m}^{2}$ and high - if more than 200 $\mathrm{m}^{2}$.

Abandoned territory or object of production. There are six land use purposes of industrial land building areas, which are specified in Cabinet Regulation No.496 (20 of June 2006) "Classification of purposes of use of real property and order of their determination and change":

- industrial enterprise building area;

- warehouse building area; 
- agricultural enterprise building area;

- fish farm and nursery building area;

- waste management company building area;

- unreclaimed industrial object building area (Nekustamā īpašuma lietošanas...., 2006).

On the other hand, the abandoned production area is the land in which production no longer takes place, and the buildings intended for production are abandoned. Abandoned production facility is an object where production has taken place in the past, but at the moment it is abandoned. For assessment of this degradation criterion we recommend to use the time factor - low degradation level could be observed in sites where the economic activity has not occurred for up to 3 years, medium degradation level - where the economic activity does not take place 3-7 years, but high - in the objects where the economic degradation does not take place for more than 7 years.

Abandoned territory or object of military purpose. Territories of military purpose belong to the group of land use purposes "Building areas of objects of national defence, security, police, fire fighting and rescue, border guards and penal institutions". To this group of land use purposes belongs built-up land on which intended use of the existing buildings is "Other, previously unclassified buildings", if they are used as buildings of penal institutions, defence forces, police and fire service buildings and yards, as well as land under these buildings and related auxiliary buildings, internal transport and maintenance of utilities these territories, land under car parking areas and garages, etc. Also, this group includes land without buildings but used land, which according to legally established use, spatial plan or detailed plan, are intended for construction of such buildings, including construction of local utilities and structures, as well as improvement elements of building areas (Nekustamā īpašuma lietošanas...., 2006).

In turn, the military contaminated area is explained in the Law "On Pollution". It is the territory where an explosive objects and materials, or toxic or otherwise hazardous substances used or intended to be used for military purposes are located (Par piesārn,ojumu, 2001). However, it should be noted that existing firing grounds of National Armed Forces of Latvia where the military trainings takes place, cannot be observed as degraded territories or objects. Only territories that during soviet period were used for military purposes but now are abandoned can be attributed to criterion "Abandoned territory or object of military purpose" (Priekslikumi zemes un.., 2016). In all areas where military actions have taken place, is possible pollution and in any case there revitalisation is necessary. Therefore, we recommend that this criterion of land degradation not divide into levels but in all cases to determine high level of degradation.

The invasive plants (hogweeds). The "Plant Protection Law" of Latvia defines invasive alien plant species as species non-characteristic to the nature of Latvia which endangers local species and their habitats or cause economic losses, damage to the environment or human health (Augu aizsardzibas likums, 1998). The Law defines only one kind of invasive plants - Sosnovsky's hogweed (Heracleum sosnowskyi Manden) in the territory of Latvia (Invazivo augu sugu..., 2008). It spreads very quickly and it is not easy to exterminate it. Evaluating land degradation we recommend to observe low degradation level if hogweeds occupy up to $30 \%$ of the total area, medium - if hogweeds occupy 31$50 \%$ of the total area, and high - if hogweeds occupy over $51 \%$ of total area.

Bogged-up land. In Cabinet Regulation No.281 (24 April 2012) "High-detail topographical information and its central database regulations" bogged-up land is characterised as wetland with less moisture than transient swamps, with moisture-grassland and with thin peat layer or without it (Augstas detalizacijas topografiskas..., 2012). Due to the fact that the bogged-up land is not a swamp yet, the land can be returned to normal humidity by means of drainage. On land where drainage systems already exist, it is easier to restore required humidity regime, but where they do not exist, they should be created. Therefore, we recommend evaluate this land degradation criterion according to the existence and quality of drainage systems. Land with existing drainage systems which require maintenance activities should be classified as land with low degradation level, if bogging-up is significant and existing drainage systems require maintenance or reconstruction activities, land should be classified as land with medium degradation level, but land should be regarded as land with high level degradation, if bogging-up is in territories without drainage systems, construction of them is necessary. 
Pollution. The purpose of the Law "On Pollution" is to prevent or reduce harm caused to human health, property or the environment due to pollution, to eliminate the consequences of harm caused, to prevent pollution resulting from polluting activities or, if it is impossible, reduce emission into soil, water and air, as well as to specify measures for investigation of polluted and potentially polluted sites and remediation of polluted sites. Polluted place within the meaning of mentioned Law is soil, subsoil, water, sludge, as well as buildings, factories or other objects containing pollutants (Par piesarnojumu, 2001). The Center for Environment, Geology and Meteorology collects information on polluted and potentially polluted places. Pollution itself is a significant factor in land degradation, regardless of its size. Therefore, all places that already are registered in the Register of polluted and potentially polluted places are considered to be with high degradation level.

In order to carry out the approbation of land degradation parameters and to evaluate degraded areas in accordance with degradation levels in the territory of agricultural and forestry activities, the field survey of the Sauka Nature Park was carried out. In order to identify land parcels affected by land degradation, the data from Cadastre information system were used. Before the field survey the spatial plan of the Sauka Nature Park was investigated and the data from following registries were used:

- the Register of spread of hogweeds;

- the Register of polluted and potentially polluted places;

- the Register of Field blocks;

- the Register of Mineral Resources and others.

Conducting field survey the data about Sauka Nature Park in mentioned registers were updated, new degraded areas and land degradation levels were determined. For determination of land degradation criteria and their levels descriptions showed in Table 2 were used. For assessment and survey of the area, additional materials - orthophotomaps and other cartographic materials were used.

\section{Discussions and results}

For approbation of research results there was selected an object - specially protected nature area Sauka Nature Park, established in 1987. The status of Natura 2000 - protected nature territory of European significance has been awarded to this park. Sauka Nature Park is located in the southeastern part of Latvia in the central part of Viesite municipality and its total area is 5635 hectares. The park is located in the highest part of the hillock Selija (Dabas parka "Sauka"..., 2010), the highest top is Ormankalns $(167 \mathrm{~m})$. There are three densely populated areas in the park - the villages Lone, Sauka and Klauce, as well as several lakes. The largest one is Sauka Lake with area 718 hectares. There are many grand-trees and separately standing trees - oaks, ash-trees, pines, rowan-trees, as well as stands of briar-roses. Important and attractive elements of the ecological landscape also are orchards with apple trees in Lone municipality. The protected area and its adjoining territories are rich with archaeological objects - cult places, castle mounds, ancient burial grounds and cemeteries, historic villages, etc., and with elements of cultural and historical landscape as such farmsteads, manorial estates, churches, roadside pubs (krogi), mills etc., constructed in the building traditions of this area. Most part of Sauka Nature Park (52\%) is occupied by agricultural land; about $31 \%$ of area is covered by forests and $14 \%$ - by land under water. There are more than one and a half hundred real properties in the park area, which consist of 613 land parcels. The average area of land parcel is 9.37 hectares. The area of smallest land parcels is about $400 \mathrm{~m}^{2}$, and they mostly are located in densely populated areas, while the area of largest land parcel is more than 700 hectares, and it is Sauka Lake. $71 \%$ of the total area of the Sauka nature park is owned by physical persons, $14 \%$ are owned by state institutions, $10 \%$ are owned by legal persons, and only $4 \%$ are owned by local municipality (Dabas parka "Sauka"..., 2010).

Conducting the survey, in the territory of the Sauka Nature Park, four degradation criteria of unmanaged agriculture and forestry activities territory were not found:

- pollution;

- uncultivated dump-site;

- abandoned territory or object of military purpose;

- abandoned territory or object of production. 
This is understandable because the Sauka Nature Park is a protected area, whose status is incompatible with nature polluting activities. However, three types of land degradation criteria were identified:

- agricultural land overgrown with shrubs;

- invasive plants (hogweeds);

- bogged-up land (Table 3, Fig. 1).

The largest degraded area consists of the land with bogging-up indicators. The investigation showed relatively large number of land parcels with over-moist soil in different degradation levels. 56 overmoist land parcels with total area of 1250 hectares were found, which makes more than $20 \%$ of total area. Low bogging-up level was detected in 33 land parcels in which existing drainage systems require maintenance and tidying up activities. There are 12 land parcels with significant bogging-up, and existing drainage systems require maintenance or reconstruction activities. High bogging-up level is detected in 11 land parcels without drainage systems, there its construction is necessary (Table 3, Fig. 1).

The agricultural land overgrown with shrubs was found in 17 land parcels with total area of 363 hectares, which makes more than $6 \%$ of the total area of park. In 14 land parcels, low level of land degradation was detected and in 3 land parcels - medium level of land degradation. In territory survey no land with high degradation level (shrubs cover more than $70 \%$ of the territory) was detected (Table 3, Fig. 1).

There also an invasive plant - Sosnovsky's hogweed was found in the territory of the Sauka Nature Park. Before field survey the information from Database about distribution of invasive plant species according to the park territory, where the presence of hogweeds were previously detected was obtained (Karte, b.g.). During the field survey the land parcels in which the hogweed vegetated wild were identified, as well as information about annihilated hogweed. Summarizing the results, it was determined that there are 8 land parcels, where hogweeds were found. The total area of invaded land is 143 hectares or $3 \%$ of park area, the presence of hogweeds was estimated with low land degradation level. At the same time it was found that within 9 land parcels hogweeds are annihilated or their active destruction was carried out (Fig. 1).

There were identified 5 land parcels which were affected by complex of land degradation criteria for example, agricultural land overgrown with shrubs together with bogging-up. Such land occupies 90 hectares or $2 \%$.

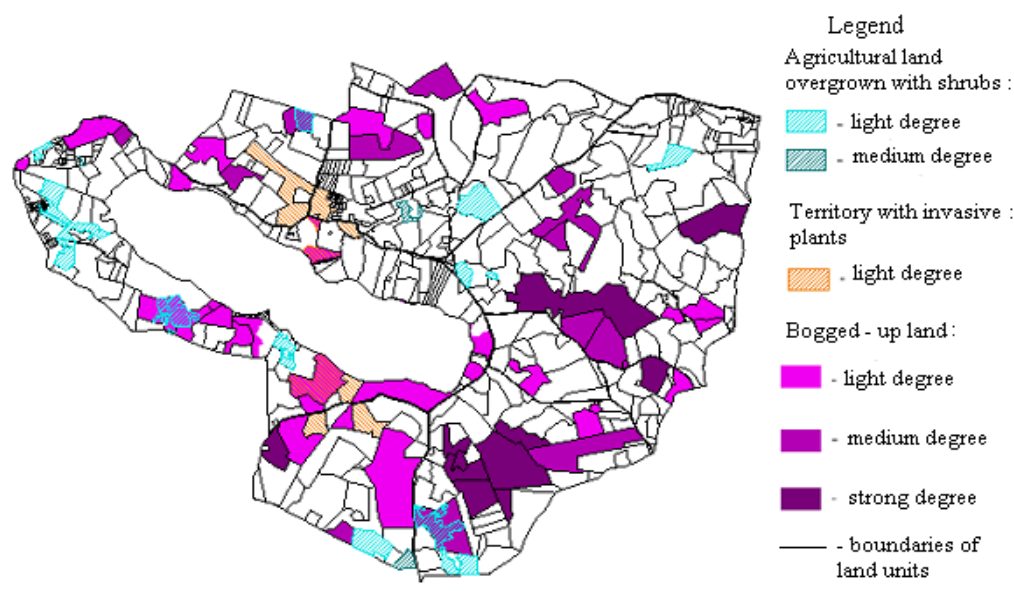

Fig. 1. Degraded territories in Sauka Nature Park

Altogether in Nature Park Sauka 86 land parcels with some features of degradation criteria were fixed. Such land takes up about 1846 hectares or almost 33\% of the total territory of the park (Fig. 1, Table 3).

Although the above figures are quite alarming, however, bearing in mind fixed degradation degree, it can be seen that the largest part of degraded land is assessed in low or medium categories. This means that the land degradation in particular area is not comprehensive, its elimination is possible, and revitalization of these territories is a further task for its owners. Furthermore, fixed reduction of area 
of hogweeds already demonstrates the results of landowner's activities. Not providing division of degradation degrees there are difficulties to assess and compare extent of land degradation.

Table 3

Summary of land degradation in the territory of Sauka Nature Park

\begin{tabular}{|c|c|c|c|}
\hline \multirow{2}{*}{ Land degradation criteria and its level } & \multicolumn{2}{|c|}{ Land parcels } & \multirow{2}{*}{$\begin{array}{c}\text { Proportion of } \\
\text { degraded } \\
\text { territories }(\%)\end{array}$} \\
\hline & number & area, ha & \\
\hline Agricultural land overgrown with shrubs, including: & 17 & 363.48 & 6,4 \\
\hline$-\quad$ low degree & 14 & 350.80 & 6.2 \\
\hline - $\quad$ medium degree & 3 & 12.68 & 0.2 \\
\hline Presence of invasive plants (hogweeds), low degree & 8 & 143.51 & 2.5 \\
\hline Bogged-up agricultural land, including: & 56 & 1249.20 & 22.2 \\
\hline$-\quad$ low degree & 33 & 630.00 & 11.2 \\
\hline - $\quad$ medium degree & 12 & 308.76 & 5.5 \\
\hline$-\quad$ high degree & 11 & 310.44 & 5.5 \\
\hline \multicolumn{4}{|c|}{ Overlap of several degradation criteria } \\
\hline $\begin{array}{l}\text { Agricultural land overgrown with shrubs together with } \\
\text { bogging-up, low degree }\end{array}$ & 1 & 15.59 & 0.3 \\
\hline $\begin{array}{l}\text { Agricultural land overgrown with shrubs (low degree) } \\
\text { together with bogging-up (medium degree) }\end{array}$ & 2 & 27.62 & 0.5 \\
\hline $\begin{array}{l}\text { Bogged-up agricultural land together with invasive plants, } \\
\text { low degree }\end{array}$ & 2 & 46.91 & 0.8 \\
\hline $\begin{array}{ll} & \text { Total } \\
\end{array}$ & 86 & 1846.31 & 32.7 \\
\hline
\end{tabular}

\section{Conclusions and proposals}

The results of the research showed that in agriculture and forestry activity territories the main criteria of land degradation are overgrowing with shrubs and bogging-up of agricultural land, as well as presence of invasive plants.

Taking into account the relatively large area of the Sauka Nature Park (5635 ha), the results of the research can be generalized as the most characteristic degradation criteria for Latvia in the areas of agricultural and forestry activities.

The approbation of land degradation criteria and their evaluation in the Sauka Nature Park suggests that a more objective view of this problem is important for the classification of degradation criteria in several degrees and justifies the assessment of land degradation.

\section{Acknowledgement}

Research has been performed in frame of Interreg Latvia - Lithuania project «Innovative brownfield regeneration for sustainable development of cross-border Regions (BrownReg)» No 325.

\section{References}

1. Augstas detalizacijas topografiskas informacijas un tas centralas datubazes noteikumi: Cabinet of Ministers of the Republik of Latvia, regulation No. 281, adopted 24 April, 2012. Vieved 13 June, 2018. (https://likumi.lv/doc.php?id=246998) (in Latvian).

2. Plant Protection Law: law of Republic of Latvia (1998). Viewed 12 June, 2018, (https://likumi.lv/ta/en/en/id/51662-plant-protection-law).

3. Regulations Regarding the Construction of Landfill Sites, the Management, Closure and Re-cultivation of Landfill Sites and Waste Dumps: Cabinet of Ministers of the Republic of Latvia, regulation No. 1032, adopted 27 December, 2011, Latvijas Vestnesis, No. 205 (4603), 30 $0^{\text {th }}$ of December, 2011.

4. Bullock P. (2005) Climate change impacts. In: Hillel D. Encyclopedia of Soils in the Environment. UK, Silsoe: Cranfield University - Silsoe, p. $254-262$.

5. Dabas parka "Sauka" dabas aizsardzibas plans (2010) / SIA "Estonian, Latvian \& Lithuanian Environment", projekta vadītājs V.Vilnitis. Riga. 127p.(in Latvian).

6. Degradeto teritoriju izpete Rigas pilseta. Petniecibas darbs (2004). Atskaite. SIA “Grupa 93”, Rigas Domes Pilsetas attistibas departaments, Riga. 66 p. (in Latvian). 
7. Degradeto teritoriju un objektu apsekojums Riga (2012). SIA „Datorkarte”. Viewed 7 June, 2018, (http://www.sus.lv/lv/petijumi/degradeto-teritoriju-un-objektu-apsekojums-riga) (in Latvian).

8. List of Invasive Alien Plant Species: Republic of Latvia Cabinet, regulation No. 468, Latvijas Vestnesis, 100 (3884), $2^{\text {th }}$ of July, 2008.

9. Jackson J.B., Finka M., Hermann G., Kliucininkas L., Lemesenoka N., Petrikova D., Pletnicka J., Teirumnieks E., Velykiene D., Vojvodíkova B., Zahnasova M., Zubkova M. (2010) Degradetas teritorijas. Rokasgramata. Starpdisciplinars macibu lidzeklis degradeto teritoriju atjaunosanai. Macibu lidzeklis Latvijai un Lietuvai. VSB-Ostravas Tehniskas universitates Buvniecības fakultate, Ostrava. 140 p.(in Latvian).

10. Karte/ Valsts augu aizsardzības dienests. Viewed 13 june, 2018, (http://karte.vaad.gov.lv/) (in Latvian).

11. Kasparinskis R. (2014) Zeme, udens, cilveks - ko sesi, to plausi! Viewed 21 May, 2018, (https://www.slideserve.com/gyda/zeme-dens-cilv-ks-ko-s-si-to-p-ausi) (in Latvian).

12. Klavins M., Nikodemus O., Seglins V. u.c. (2008) Vides zinātne. Riga: LU Akademiskais apgads. 599 p.(in Latvian).

13. Kust, G., Andreeva, O., \& Cowie, A. (2016). Land Degradation Neutrality: Concept development, practical applications and assessment. Journal of Environmental Management. Vieved 7 June, 2018, (https://doi.org/10.1016/j.jenvman.2016.10.043).

14. Latvanu izplatiba: Valsts augu aizsardzibas dienesta majaslapa. Viewed 12 June, 2018, (http://www.vaad.gov.lv/sakums/informacija-sabiedribai/par-latviju-bez-latvaniem/meklet-latvanu-invadetoteritoriju.aspx)(in Latvian).

15. Nekustama ipasuma lietosanas merku klasifikacija un nekustama ipasuma lietosanas merku noteiksanas un mainas kartiba: Ministru kabineta 2006. gada 20. jūnija noteikumi Nr. 496. Latvijas Vestnesis, No. 108 (3476), $11^{\text {th }}$ of July, 2006 (in Latvian).

16. On Pollution: law of Republic of Latvia (2001), Latvijas Vestnesis, No.51 (2438), $29^{\text {th }}$ of March, 2001.

17. Parsova V., Jankava A., Kukule I. (2017) Determination of land degradation for sustainable development of municipal territories. BGC Geomatics 2017: Baltic Geodetic Congress (Geomatics): proceedings, Gdansk, Poland, 22-25 June 2017 / Gdansk University of Technology. Gdansk, p. 158-162.

18. Piesarnoto un potenciali piesarnoto vietu registrs / LVG̣MC. Viewed 13 June, 2018,

(https://www.meteo.lv/lapas/vide/piesarnoto-un-potenciali-piesarnoto-vietu-registrs/piesarnoto-un-potencialipiesarnoto-vietu-registrs?id=1527\&nid=373) (in Latvian).

19. Priekslikumi zemes un augsnes degradacijas klasifikacijas, kriteriju un novertesanas kartibas izstradei (2016). VARAM, etapa Nr. II, priekslikumu gala redakcija 2016. 98 p. (in Latvian).

20. Puce A. (2006) Centisies mazinat Nicas zemes degradaciju. Viewed: 04 June, 2018, (http://www.tvnet.lv/zinas/ekologija/171279-centisies_mazinat_nicas_zemes_degradaciju) (in Latvian).

21. Sklenicka P. (2016). Classification of farmland ownership fragmentation as a cause of land degradation: A review on typology, consequences, and remedies. Land Use Policy, 57, 694-701. Viewed: 04 June, 2018, (https://doi.org/10.1016/j.landusepol.2016.06.032).

22. Land Management Law: law of Republic of Latvia (2014). Latvijas Vestnesis, No. 228 (5288), $15^{\text {th }}$ of November, 2014.

Information about authors

Anda Jankava, Dr.oec., professor, Department of Land Management and Geodesy of Latvia University of Life Sciences and Technologies. Address: 19, Akademijas str., Jelgava, LV-3001, phone: +371 29356448, e-mail: Anda.Jankava@llu.lv

Velta Parsova, Dr.oec., professor, Department of Land Management and Geodesy of Latvia University of Life Sciences and Technologies. Address: 19, Akademijas str., Jelgava, LV-3001, phone: +371 29118285, e-mail: velta@parsova.lv

Eva Laizāne, Bs.sc.ing., assistent, Department of Land Management and Geodesy of Latvia University of Life Sciences and Technologies. Address: 19, Akademijas str., Jelgava, LV-3001, phone: +37129193752, e-mail: evalaizane@inbox.lv

Maija Berzina, Mg.sc.ing., assist. professor, Department of Land Management and Geodesy of Latvia University of Life Sciences and Technologies. Address: 19, Akademijas str., Jelgava, LV-3001, phone: +37129193752, e-mail: maija.berzinaaa@gmail.com

Aina Palabinska, Mg.oec., lecturer, Department of Land Management and Geodesy of Latvia University of Life Sciences and Technologies. Address: 19, Akademijas str., Jelgava, LV-3001, phone: +37126358542, e-mail: Aina.Palabinska@1lu.lv 